\title{
Chapter 6 \\ Economic Gerontology: Older People as Consumers and Workers
}

\author{
Jolanta Perek-Bialas and Joop J. Schippers
}

\subsection{Summary and Learning Goals}

This chapter discusses older people's roles in the economy. It considers them in their role as workers who sell their manpower in the labour market, and as consumers who purchase goods and services. In Europe, the situation of older workers is currently strongly debated, and several governments have implemented reforms trying to encourage people to work until a later age. Older Europeans' consumption patterns differ markedly from the ones of younger individuals, e.g. in that older people spend less money. Finally, this chapter discusses how the economic crisis might affect older Europeans.

After reading this chapter, you should be able to:

- Describe how consumption patterns change over the life course

- Describe challenges that older workers encounter

- Explain what policy-makers could do to support older workers

- Discuss how the economic crisis could impact older Europeans

\subsection{What is Economic Gerontology?}

In this chapter, we would like to jointly treat economics and gerontology, seeing it as one sub-discipline in the framework of gerontology called economic gerontology. On the one hand, gerontology is the scientific study of the biological, psychological and social aspects of ageing — as it is stated by Quadagno (2011). On the other hand, economics is the social science that primarily studies choices and focuses on the production, distribution, and consumption of goods and services. From the perspective of economic gerontology, we will therefore be interested in the analysis of

\footnotetext{
J. Perek-Bialas $(\bowtie)$

Institute of Statistics and Demography, Warsaw School of Economics, Institute of Sociology,

Jagiellonian University, Cracow, Poland

e-mail:.jperek@sgh.waw.pl

J. J. Schippers

Faculty of Law, Economics and Governance, Universiteit Utrecht, Utrecht, The Netherlands
}

K. Komp and M. Aartsen (eds.), Old Age in Europe, SpringerBriefs in Aging, DOI: 10.1007/978-94-007-6134-6_6, (C) The Author(s) 2013 
the consequences for the production, distribution and consumption of the process of population ageing. In other words, economic gerontology considers older people's roles in and for the economy. It considers them in their role as workers who sell their manpower in the labour market. It also considers them in their role as consumers who purchase goods and services. Moreover, it considers them in their role as tax payers and consumers of public services, like care. ${ }^{1}$

\subsection{Central Theories and Concepts in Economic Gerontology}

There is a variety of theories on ageing, which are well described and presented, with a division-like in economics-between micro theories of ageing (these are related to issues of individual ageing ${ }^{2}$ ) and macro theories (here ageing is a part of the social structure, i.e. relation between age and social status). An influential theory in Europe is the activity theory (Havighurst et al. 1968), which assumes that older persons age optimally if they stay active and manage to resist the shrinkage of their social worlds (Havighurst et al. 1968, p. 161). The impact of this theory is visible in the active ageing concept_-popular in Europe-which could be understood as the process of optimizing opportunities for health, participation and security in order to enhance quality of life as people age (World Health Organization 2002, p. 12). However, researchers discuss whether this concept includes all issues relevant from the perspective of ageing studies, and whether European policy-makers take it on board (Walker and Maltby 2012). These discussions sometimes also tackle the topic of successful ageing, as it was introduced by Havighurst (see Chap. 4 on Social Gerontology). Related to economic theory is the so-called social exchange theory. This theory, which is often used in sociological research, claims that the behaviour of individuals (including social interactions) is rational and based on people's interest to maximize their profits and minimize their costs (Marshall 1996). Individuals are interested in exchange with other individuals as long as the benefits of this exchange are greater than costs associated with it. In this understanding, older generations could be perceived as those with lower resources, poorer health and low education. Consequently, members of younger generations do not have a motive for exchanges with them. However, many analyses of care within families show that the care for older parents/family member is provided thanks to love or other emotions, pointing to the fact that not only rational arguments and calculations are important (see the results of the EUROFAMCARE project ${ }^{3}$ ). Also, studies showed that intergenerational transfers

\footnotetext{
${ }^{1}$ For information about the economics of ageing, see Schulz (2001), Wise (2009, 2010).

${ }^{2}$ For an excellent overview of theories of ageing, see Quadagno (2011).

${ }^{3}$ EUROFAMCARE project about Services for Supporting Family Carers of Elderly People in Europe: Characteristics, Coverage and Usage, see http://www.uke.de/extern/eurofamcare/.
} 
between family members are still strong in Europe, not only in the Mediterranean countries, but also in Central and Eastern Europe (Litwin and Attias-Donfut 2009).

The other important theory-from the point of view of the current chapteris the modernization theory of Cowgill (1974), which claims that social changes devalue the position of older people. This theory distinguishes four types of social changes that affect the position of older persons: health technology, economic technology, urbanization and mass education. These changes are lowering the status of older people and favour youth. However, the modernization theory was criticized heavily and nowadays the age stratification theory seems to be more influential (see i.e. Riley 1971). Here, age is defined as an element of social organization as the ageing process and age structures form a system of interdependent parts that we refer to as an'age stratification system' (Riley et al. 1988, p. 243; Riley and Riley 2000). Besides in theories which are more appropriate to be mentioned in an overview of political gerontology, the interest of old age and ageing are also considered from an economic perspective in feminist theories.

However, compared to social sciences like sociology or (social) psychology, economics as a scientific discipline is rather underdeveloped when it comes to the 'gerontology of economics' or 'economic gerontology'. There is no economics equivalent to the SAGE handbook of social gerontology (Dannefer and Phillipson 2010). Also an impressive volume like the Encyclopedia of Gerontology (Birren 2007) does not include any substantial and serious contributions on economics. Even though Estes and Phillipson (2007), Estes (2001/2009) and Polivka and Estes (2009) talk about 'the political economy of aging', their primary orientation is on social policy, which is-of course-very important, but only covers a small part of the wide range of topics economists usually study and which will be influenced by the ageing of the population. That is why in this chapter we opt for a broader approach that is not limited to the consequences of ageing for the health system, social policy or the pension system, but addresses the whole economic circle, including also consumption, saving and the labour market.

In order to present a systematic analysis of the economic consequences of an ageing population, we will depart from a basic circular model like the ones that are included in many economic textbooks to describe the main flows and relations in a country's economy (see Fig. 6.1).

The model in Fig. 6.1 illustrates the different roles that individuals play in the economy. They sell their working hours in the labour market. In exchange, they get paid and with the earnings they make they can buy commodities and services in the markets for goods and services. To produce these goods and services, entrepreneurs hire workers in the labour market. These relations constitute the economic circle that is the foundation of every market economy. Yet, in most national economies the picture is slightly more complicated. Some citizens earn enough to be able to save part of their income. These savings go to the capital market (usually with banks as intermediate institutions). In these capital markets, the same entrepreneurs that hire workers to produce goods and services borrow these savings again to build production plants, buy machines or lorries, equip offices etc. We call such items capital goods. In most modern economies, individual citizens can or have to spend their earnings 


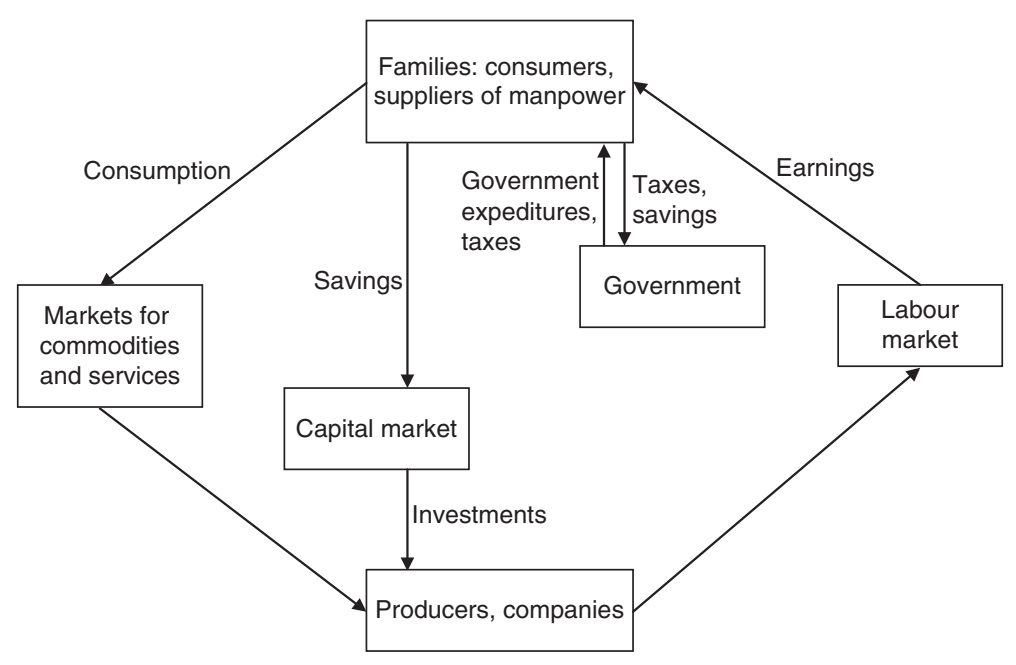

Fig. 6.1 The economic circle and the basic flow of money

on a third category, i.e. taxes to be paid to the government. In return the government 'produces' all kinds of (public) goods and services, like the police and the fire brigade, laws, a legal system with judges, in many countries an army to defend the nation, and sometimes dykes to protect the land against the sea. Depending on the type of welfare state, the government is also responsible for the provision of education, child care, health and social security, though countries differ very much with respect to the extent of government intervention in these domains. Public pensions are included in government expenditures, while social premiums to pay for these public pensions in case of a pay-as-you-go pension system are included in the taxes paid by all workers/all inhabitants. Private pensions stem from (former) employers and are included in the earnings stream to families. These private pensions are paid from a fund kept/organised by employers and fostered from a share of the wages of employees withheld during earlier stages of their life course. Thus, the circle includes both individuals who are still in the labour market and those who have retired already.

\subsection{What Does Economic Gerontology Tell Us about the Current State of Europe?}

Economic gerontology helps us to capture the role of older people in the economy. In the following pages, we will use it to gain an overview of the situation in Europe. ${ }^{4}$ For this purpose, we will first look at income and poverty, then at consumption and savings, and finally at older workers and their place in the labour market.

\footnotetext{
${ }^{4}$ For more information, see the 'Survey of Health, Ageing and Retirement in Europe', which studies the situation of Europeans aged 50+ http://www.share-project.org/.
} 


\subsubsection{Income and Poverty over the Life Course and in Old Age}

For economists, the issue of income is essential for the explanation of the wealth of society. Looking at the development of income over the life course, a common finding is that when we are young, still in school and not working yet, we do not have an income of our own. Next, at the beginning of the working career, most individuals start earning an income, but wages are still modest as a new worker is not yet very experienced and still earns less than a skilled worker. During their careers, most people become more experienced, move to higher jobs, and see their earnings increase, even though at different paces. This development of income over the life course has been extensively discussed by the human capital theory (Becker 1962; Polachek and Siebert 1993). When workers retire from the labour market they usually see their income fall. The extent to which income falls after retirement depends on the pension system in various economic countries.

Table 6.1 shows the level of income at various stages of the life course for a selection of European countries. We did select these eight countries because they present a representative picture for the whole of Europe. The pattern is the same for all countries, though at a different level and with greater and smaller variation over the life course.

Of course, these figures do not represent 'real' life-course patterns, because they relate to income statistics for different cohorts at one singular point in time. Those who are over 65 years now had much lower incomes when they were under 18 than the current cohorts under 18. In a similar way, future older people will probably be richer than past and current cohorts of older people. Thus, individual life-income patters do have a parabolic shape, but less steep than Table 6.1 suggests.

Additionally, income is a key variable in calculating poverty rates, which are a crucial indicator for whether and where intervention for older persons is needed. Time series data for several European countries show that for the group of people aged $65+$ years, the median income is lower than that for the group of persons aged 18-64 years (Atkinson and Marlier 2010). The general picture shows that the income of the $65+$ age category is gradually rising over time. However, as the available income figures have not been corrected for inflation, one cannot be sure that the rise in income represents an increase in welfare and purchasing power, too.

Of course, a lower income after retirement does not automatically implicate that people in this age category are poor. According to a definition of poverty used in several countries, the poverty threshold lies at $60 \%$ of the national median income. Using this definition, older persons are not the most vulnerable groups in many countries, unlike for instance the unemployed, single mothers and families with many children. However, also within the age group $65+$ years, one may find wide differences. Usually, retired women are in a much worse financial situation than retired men. This worse financial situation is not only caused by different methods of calculating pension benefits and the longer average life expectancy of 
Table 6.1 Income by age groups, 2005 and 2010

\begin{tabular}{llll}
\hline Country & Age group (in years) & Income (in Euros) & \\
\cline { 3 - 4 } & & In 2005 & In 2010 \\
\hline Denmark & Below 18 & 21,996 & 25,817 \\
& $18-64$ & 23,759 & 27,695 \\
Germany & 65 and older & 16,298 & 19,342 \\
& Below 18 & 14,934 & 17,607 \\
& $18-64$ & 17,194 & 20,000 \\
France & 65 and older & 15,650 & 17,167 \\
& Below 18 & 14,790 & 18,222 \\
Italy & $18-64$ & 16,796 & 20,717 \\
& 65 and older & 14,549 & 19,998 \\
& Below 18 & 12,782 & 13,799 \\
The Netherlands & $18-64$ & 15,471 & 17,082 \\
& 65 and older & 12,592 & 14,939 \\
& Below 18 & 15,310 & 18,920 \\
Poland & $18-64$ & 18,198 & 21,478 \\
& 65 and older & 15,261 & 18,041 \\
& Below 18 & 2,162 & 4,048 \\
Sweden & $18-64$ & 2,588 & 4,584 \\
& 65 and older & 2,702 & 4,146 \\
& Below 18 & 16,414 & 18,965 \\
UK & $18-64$ & 18,981 & 20,990 \\
& 65 and older & 14,692 & 16,127 \\
& Below 18 & 16,622 & 15,203 \\
& $18-64$ & 20,697 & 18,873 \\
& 65 and older & 14,590 & 14,524 \\
\hline Eves & &
\end{tabular}

(Eurostat 2012c)

Note The income is the median equivalised income, it has not been corrected for inflation

women, but also by the fact that during the whole life course women have been doing additional, unpaid tasks outside the labour market (like childcare, housework etc.) which prevented them from spending as much time and effort on their labour market career as men and which is not rewarded in most pension systems. For a more detailed picture of the income position and the risk of poverty of older people across Europe, we would like to refer to Jehoel-Gijsbers and Vrooman (2008), Vrooman (2008) and Zaidi (2010).

\subsubsection{Consumption over the Life Course and Older Consumers}

Population ageing in Europe entails that older consumers become more numerous. Are older consumers likely to behave differently from younger consumers? There are several reasons to answer this question affirmatively. Already, intuition may 
point to the fact that younger people are engaged in different activities than older people. Children play with toys, adolescents may ride a surf board, while older people may go to the museum more often or work in their garden to grow vegetables. Each of these activities is related to the consumption of different goods and services. In general, one may point to the fact that during the course of their lives, older people usually have been able to acquire some wealth (it could be a house, a car, furniture, a TV set and a washing machine, and most of the things needed when a new-usually young - household is established). Therefore, one might hypothesize that basic consumer durables will be bought more often by younger and middle aged people than by people over fifty or sixty. Next, young people who are still growing physically or workers in their forties who work in construction need more calories and will eat more than older people. In addition, retired people who spend more time at home and maybe sit on the couch more often, reading a book or watching television may spend more money on heating their home than younger people who are at school or at work most of the day. On the other hand, as older people — especially after retirement-have more leisure time they may spend a larger share of their income on going to the theatre, a trip to another town to visit a special exhibition or going to the zoo with their grandchildren. Moreover, due to declining physical or cognitive capacities, older people might more often consult their general practitioner or a physiotherapist. Consequently, one might expect a shift in consumption from 'goods' to 'services' throughout the life course.

Figure 6.2 presents information on consumption in a selection of European countries. The general picture presented here supports the idea that consumption shows a parabolic development over the life course. In all countries except Poland consumption reaches a maximum for the age category $45-59$ years old and declines afterwards. This development is similar to the development of earnings over the life course presented above. Of course, here the same caveat holds that the information included in the graph does not stem from longitudinal data, but instead describes the behaviour of different generations. People currently in their 30s will probably show different consumption patterns when they will be in their $60 \mathrm{~s}$ or $70 \mathrm{~s}$ than those who are in these age brackets today. Moreover, the figures do not reveal which share of their income individuals of various age categories spend on consumption.

Detailed analyses of consumption expenditure patterns (e.g. from the Eurostat database) gives us more information of the development of various categories of consumption over the life course. While the consumption of food and nonalcoholic beverages is more or less stable over the life course, the expenditures on clothing and footwear show a clear tendency to fall when we analyse the shares of total expenditures. Looking at spending on rent, we see that during the first stage of the life course many individuals have not yet settled down and live in rented places. During their thirties and forties they settle down, have saved some money and buy a place of their own. The number of house owners reaches its peak for the age category 45-69 years and decreases afterwards, because in some European countries older people sell their houses (e.g. because the children have moved out or because they move to an old age home). In contrast with the expenditures on food 


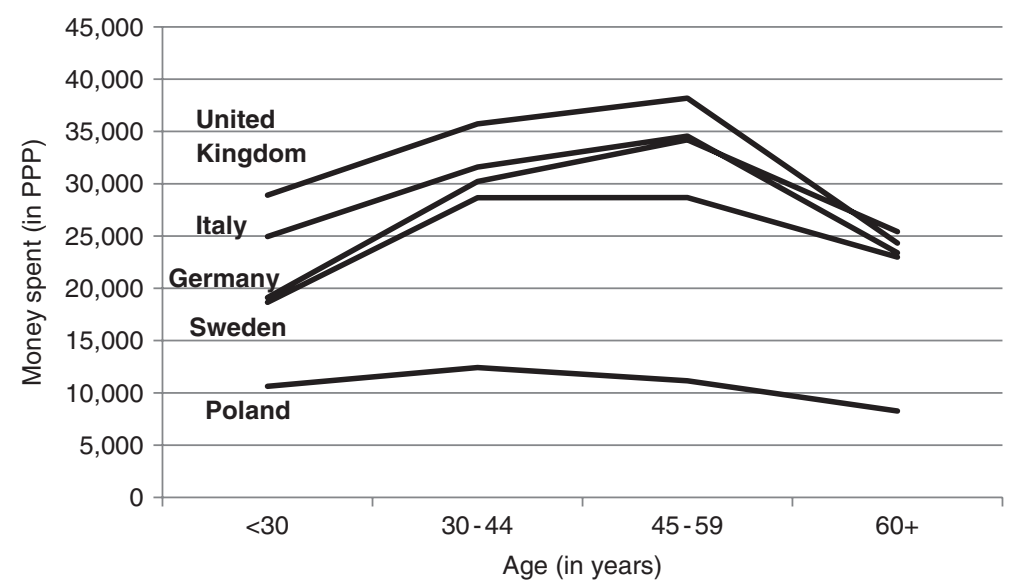

Fig. 6.2 How much money people spend (in PPP), in 2005 (Eurostat 2009). Note PPP means 'purchasing power parity'. PPP tells us how much money would be needed to buy the same goods and services in different countries. Using PPP is helpful when we compare countries with different currencies (like Euros and Polish zloty), because then we do not have to pay attention to foreign exchange rates

and clothing, the expenditures on rent for housing show wide differences between countries. These differences reflect both cultural and institutional variation between European countries. As expected, the expenditures on electricity, gas and other fuels are more or less stable as long as most people still spend most of their days away from home (at school or in the labour market) and increases after the age of 60. Health expenditures show a tendency - as expected-to increase over the life course. This increase already starts for the age category 45-59 and continues from there on. While older people spend more money on health, their expenditures on education are very low. Expenditures on transportation are stable during working life and drop in almost all countries when people retire and do not commute to work every day any longer. Other expenditures like expenditures on recreation and culture remain stable after retirement (in some countries one can observe an increasing trend, like in Germany, while in others, like Poland, the trend is decreasing). Expenditures on restaurants and hotels slowly decline over the life course.

Consequently, if consumer behaviour would not change in the future, population ageing would result in less consumption overall, in less expenditures on clothing and footwear, on education, and on restaurants and hotels, and in more expenditures on rent for housing, on electricity, and on health care. However, the consumption behaviour of future generations is unlikely to remain the same as that of past generations. First, the supply and availability of consumer goods and services is changing all of the time. One sees this in the field of information and communication technologies, but also in the field of health or in that of recreation. People have more options to choose and it is almost impossible to predict which options they will actually choose. Second, people of current generations are much healthier than those of previous generations. Many of today's older people are 
energetic and healthy, have hobbies, travel, and maybe even start their own business. These changes in opportunities and changes in behaviour may give rise to what is sometimes called 'a silver economy': an economy with all kinds of new products and services, particularly aimed at the growing share of healthy, wealthy senior citizens. Of course, this development may be different for various countries, depending on their wealth and the general health of the (senior) population. Interesting developments concerning a 'silver economy' can be found in some Western European countries (Germany, France and others), while such initiatives have not yet developed in most Central and Eastern European countries. ${ }^{5}$

\subsubsection{Savings}

To a large extent, saving behaviour and saving patterns reflect consumption behaviour and consumption patterns. Young people who still have low earnings and high expenditures on consumption to build up their household are likely to spend a large share of their income on consumption. This leaves them with little opportunity for savings. If income increases over the life course and many desires on consumption have been fulfilled there may be more room for savings, especially after the children have grown up. From a theoretical perspective it is often hypothesized that individuals may want to put money aside during their fourties and fifties, while they are still in the prime of their life and active in the labour market to save it for the 'rainy days' after retirement. As a matter of fact, in some countries with capital funded (additional) old age pensions (like the Netherlands and the United Kingdom) these savings are even obligatory: every month the employer puts part of the workers' wages into a special pension fund. From this fund workers get (additional) benefits after retirement (on top of their public pensions based on a pay-as-you-go system). In general —as we have seen already above-individuals' income falls after retirement, but so does consumption. Whether income or consumption declines faster as people age cannot be predicted beforehand. Empirical evidence has to provide the answer to this question. The older people get, the lower the necessity for savings, unless older people want to leave a large inheritance to their surviving relatives.

Consequently, at the macro level, one may expect that the higher the share of the population in retirement, the lower the share of savings in national income and the larger the withdrawals from private saving accounts and pension funds. However, this relation may be obscured by the availability of public provisions, for instance in the field of health care. If older people have to pay for health care themselves, they may need much more savings for the last years of their life than in case of the availability of an extensive public health insurance system. On the other hand, the need for savings depends on the national situation in housing. In countries where many

5 For more details, see http://www.silvereconomy-europe.org/. 
families own their own houses, older people may often be in a position where their mortgage has been paid off and living expenses are low. This will give room for savings, even in old age. In countries where most families live in rented houses, people will have to pay rent until the end of their lives, which leaves them less room for savings. Moreover, the saving behavior is related to the feeling of being uncertain about one's future, and Hershey's et al. (2010) analysis clearly shows that there are differences across nations in the degree of retirement worries, as well as differences in the propensity to save for the future. While low levels of worry can be observed in Scandinavian countries and the Netherlands, Europeans from Eastern Europe reported high levels of worry. Yet, in those countries, saving for old age is not so popular.

\subsubsection{Older Workers}

Most contributions that have been made so far to the scientific field of the (sub) discipline of economic gerontology are related to the labour market. This has probably to do with the fact that the labour market is much more sensitive to the ageing of the population than consumer markets. No matter what their age is, individuals keep buying food and clothes, they need a place to live, and they need to heat that place during the winter. As we have seen, consumption fluctuates over the life course, but it does not come to a halt after a certain age. This is, however, precisely what happens in the labour market. At some age, most people that are in the labour market retire and stop working for pay (see Chap. 5 on Political Gerontology). This holds in particular for the large share of employees within the work force. Farmers and self-employed individuals often keep on working until the end of their lives. However, their share of the workforce has been decreasing over the past century. According to the latest Eurostat data, in general $41 \%$ of men and $59 \%$ of women in the age group 55-64 years are inactive. This is mirrored by low employment rates for older workers in the age group 55-64 years (see Table 6.2). However, there are countries like Sweden with more than $70 \%$ of those between 55 and 64 years employed, but also countries like Poland with an employment rate for this age group of about $30 \%$. It is still evident that persons aged 55-64 years are less active on the labour market than younger age groups. Inactivity of individuals in this age bracket is not only caused by (early) retirement, but also by illness, disability, and unemployment.

Many workers belonging to the cohorts that are now in their fifties and sixties started working at a relatively young age, in the middle of their teens. At that time, most jobs were to be found in manufacturing and agriculture and many of the jobs were physically demanding. In addition, protective measures (against dust, noise, heat or cold, security clothing) were not yet as well developed as they are nowadays. Consequently, many members of these cohorts who have been working for forty years or longer in these physically demanding jobs are worn out by the time they reach the age of 55 or 60 and/or suffer from some kind of disease. Therefore, among disabled workers the share of older workers is relatively high. 
Table 6.2 Employment rate of Europeans aged 55-64 years (in \%), in 2000 and 2011

\begin{tabular}{lllllll}
\hline & Total & & & \multicolumn{3}{l}{ By educational level (2011) } \\
\cline { 2 - 3 } \cline { 6 - 7 } & 2000 & 2011 & & Low & Intermediate & High \\
\hline Denmark & 55 & 59 & 48 & 59 & 72 \\
France & 29 & 41 & 34 & 42 & 57 \\
Germany & 37 & 60 & 42 & 58 & 74 \\
Italy & 27 & 37 & 26 & 50 & 68 \\
Netherlands & 38 & 56 & 44 & 58 & 71 \\
Poland & 29 & 37 & 23 & 37 & 58 \\
Sweden & 64 & 73 & 63 & 73 & 82 \\
United Kingdom & 50 & 57 & 43 & 62 & 65 \\
\hline
\end{tabular}

(Eurostat 2012a, b)

While research shows that physical capacities decrease over the life course and on average younger workers are in a better physical condition than older workers, older workers may also become obsolete from an economic perspective. When young people go to school, they accumulate all kinds of knowledge and skills and when they enter the labour market they are the ones embodying the state of the art in their profession or discipline. During their career they get more experienced in performing their job, but their knowledge may become out-dated as technological development goes on and new findings are introduced in the work process. Of course, additional training can compensate for this loss of 'human capital'. However, at some point during the life course both individuals and their employers become reluctant to invest any more in additional training and the development of new skills as the payback period shortens, i.e. the time the employer and the employee will benefit from these additional investments. So, what we see is that training activities decline after the age of 45 or 50 years and come almost to a halt at the age of 60 years. As a consequence, many older workers remain afloat in their professional life based on the knowledge they acquired in the past (De Grip and Van Loo 2002; Mayhew and Rijkers 2004; Thijssen and Van der Heijden 2003; Thijssen and Walter 2006). This makes them particularly vulnerable in times of economic downturn or crisis. If employers have to reduce their staff, they may prefer to retain their most productive workers (Taylor and Walker 1998; Parsons 1972; Boxall and Purcell 2003; Dorn and Sousa-Poza 2010). Unless older workers possess some specific talents, employers will often prefer to retain those workers who embody most recent skills and knowledge and who are physically fit to do the job. It, of course also depends on national laws concerning redundancies to what extend employers can follow their economic preferences and to what extend older workers will be protected (as a case of Poland, four years before the retirement eligible age the worker cannot be laid off). However, it has to be indicated that there are various possibilities of using performances and skills of older people in the labour market (e.g. via mentoring system in the companies).

Bearing in mind the causes for disability and unemployment of older workers, it should not come as a surprise that there is a strong correlation between older 
people's labour force participation and education. First, highly educated individuals enter the labour market later than lower educated individuals. Therefore, at the age of 55 or 60 years, the higher educated have been working fewer years than their lower educated colleagues. In addition, highly educated workers often work in so-called white collar office jobs, which may be less demanding from the perspective of physical health. As the initial learning abilities of highly educated workers are higher, they may also find it easier to pick up new knowledge during the course of their career. This might protect them against (part of) the depreciation of their human capital.

If future cohorts of workers were to show retirement patterns similar to current ones, this would imply an ever smaller workforce. This ever smaller workforce would have to generate income for an increasing group of retirees, unless-of course-these retirees would have saved enough money for their old age themselves. In most countries this is not the case, and even countries with well-developed private pension funds and high private pension savings like the Netherlands will have to deal with increasing health and public pension costs as the group of retirees grows.

That is why in 2000, European government leaders have develop the so-called 'Lisbon strategy' aimed at-among other things-increasing the share of the 50+ population active in the labour market. Bearing in mind that the life expectancy of men and women in Europe is still rising (see Chap. 1), part of the strategy to increase the support for the future welfare state has been and still is the increase of the official retirement age. In most European countries this retirement age is 65 years, but several European governments have already decided that this official retirement age should be increased (for example in Germany, Sweden, France, the Netherlands, Belgium and Poland), immediately or in the next few years. In some countries, this has resulted in social unrest and strikes. Next to that, it is noteworthy to examine how employers look at the ageing of the work force and its consequences. Because, in the end, even if individual workers want to continue working until a higher age, it still depends on the employers whether they will be able to realize this goal.

Taylor and Walker (1994) were among the first to analyze the organizational response to an ageing work force. One of their findings (later on quite often confirmed by others) is that employers assume older workers to lack appropriate and adequate skills. In many studies (e.g. Taylor and Walker 1998) about perceptions of older versus younger workers, one can find the typical pattern that older workers are appreciated for their loyalty, reliability, and even productivity (e.g. in the United Kingdom, employers value older over younger workers in terms of productivity, see Van Dalen et al. 2009). However, employers' most negative opinions about older workers' are those related to their inability to deal with new technology, resistance to change, lack of flexibility in adjusting to changing market demands, and lack of willingness to collaborate with younger superiors. All these stereotypical beliefs negatively affect employers' attitudes and behaviours towards older workers. Employers-driven by negative attitudes and the desire to reduce the labour cost—could send workers into retirement (see employers' strategies towards older workers at the company-level in Poland, Perek-Białas and Turek 2012). In spite of the perceived demographic challenges ahead, employers in some countries_-such as Greece, Spain and the Netherlands-did not take substantial 
measures to retain and recruit older workers or improve their productivity, contrary to employers in the United Kingdom, who recognized older workers as a valuable source of labour supply and have implemented measures which allow to keep older workers not only in the companies but also in the labour market (Van Dalen et al. 2009).

Recent analyses show how European employers look at various dimensions of productivity of older and younger workers. For instance, $50 \%$ of employers associate 'flexibility' with younger workers, while only $20 \%$ associate flexibility with older workers. The analysis shows that older workers have better scores on socalled 'soft skills', while younger workers are perceived to perform better on 'hard skills’ (Aleksandrowicz 2011).

\subsection{Current Debate in Economic Gerontology: How Does the Economic Crisis Affect Older Individuals?}

In Europe, the tone of economic considerations on old age currently sharpens because of the economic crisis of 2008. This crisis drives old age poverty, it leads companies to foreclose, and it tightens public budgets at the same time. These developments give more weight to questions of economic sustainability and they will bring forward changes that will still persist even after the economic crisis subsided.

An important fact in times of economic crisis is that future opportunities of older workers do not only depend on employers' views on older and younger workers' qualities, but also on how they perceive these qualities in relation to labour costs. Many European employers foresee an (un)balance between labour costs and productivity (Schippers et al. 2011). While human capital theory predicts that workers' productivity will decrease as they get older, in many countries institutional arrangements provide for age or experience related wage schemes and different forms of seniority payment. Table 6.3 shows employers' beliefs on what will happen with labour costs and productivity, respectively, if the average age of their staff increases by 5 years.

Table 6.3 What employers think will happen if the average age of their employees increases by 5 years (in \%), in 2009

\begin{tabular}{|c|c|c|c|c|c|c|}
\hline & \multicolumn{3}{|c|}{ Labour costs } & \multicolumn{3}{|c|}{ Productivity } \\
\hline & Higher & No change & Lower & Higher & No change & Lower \\
\hline Denmark & 33 & 61 & 6 & 10 & 71 & 19 \\
\hline France & 51 & 43 & 6 & 8 & 64 & 28 \\
\hline Germany & 48 & 51 & 1 & 10 & 54 & 36 \\
\hline Italy & 49 & 48 & 3 & 14 & 61 & 25 \\
\hline Netherlands & 75 & 24 & 1 & 8 & 58 & 34 \\
\hline Poland & 16 & 74 & 10 & 10 & 61 & 29 \\
\hline Sweden & 44 & 50 & 6 & 8 & 55 & 37 \\
\hline
\end{tabular}

(Own calculations with data from the project 'Activating Senior Potential in Ageing Europe') 
While a majority of employers (about $60 \%$ ) expects productivity to stay the same if the age of their staff increases by five years, about $30 \%$ expects a decrease and only a small $10 \%$ expects an increase in productivity. The figures on the expectations with respect to labour costs more or less mirror the expectations with respect to productivity. The limited number of employers expecting productivity gains contrasts with a much higher share that expects labour costs to increase. The expectations with respect to the evolution of labour costs, however, show a much larger variety than the expectations with respect to productivity. The combination of the expectations on labour costs and productivity put older workers in a relatively unfavourable position. Of course, there are major differences between countries. Dutch employers are the most skeptical ones when it comes to the expectations regarding older workers. In Poland, on the contrary, there is much less fear for an imbalance between productivity and labour costs when the staff grows older.

It is important to briefly consider the effects of the current economic crisis on the situation of older people in the labour market. The economic crisis has several effects on older people. First, there is the risk that (relatively expensive) older workers may lose their jobs and, once unemployed, remain unemployed until the official retirement age. Several countries already show a high share of older people among the long-term unemployed. As growing unemployment mitigates the effect of ageing and dejuvenation, employers (and governments) may not feel the urgency of increasing older workers' labour market participation any longer. This may be detrimental for earlier initiatives to promote older workers' employment. Another effect of the crisis may be the loss of retirement savings and lower private pensions, due to lower yields in the stock market. Public pensions may decreased due to the necessity for cut backs in public spending. Lower pensions may increase the share of the poor among the elderly and the need to keep on working beyond the official retirement age. Moreover, the proposed extension of European rules on (risky commercial) banking to (less risky and well organized) private pension funds may result in lower private pensions and harm those people in Europe that have been saving throughout their life course by participating in such a private pension fund.

We also have to remember that population ageing may have substantial consequences for the public sector economy. First, with respect to taxes, one may expect that the increase of the number of retirees will result in lower revenues from income taxes. In addition, if older people consume less than people who are still in their primes, then the revenues from consumption related taxes (like Value Added Tax) will also fall. Therefore, the main source of revenues to pay for public expenditures is likely to shrink.

What is there to be expected with respect to various categories of public expenditures? Of course, an ageing society may need less public spending on education. If the number of children born every year is declining there is-if everything else stays the same-less need for child care facilities, schools and teachers. At the other side of the age spectrum, one may expect a higher demand for care and health services. Whether this implies higher public expenditures primarily depends on the (national) institutional arrangements with respect to the (health) 
care system. In several countries there is already an ongoing debate on what kind of services and facilities should be provided by public authorities (paid for from taxes) and what by private parties (paid for directly by the clients themselves). Some politicians argue that just like a child's tricycle is not financed from public money, in a similar way older people should pay for their reading glasses or rollators themselves.

As the number of citizens over the official retirement age increases, the number of people entitled to public pensions also increases. If these retirees live longer than their predecessors, public pension expenditures will increase even stronger. As discussed in the previous section, in many European countries there is a debate going on about the necessity and the possibilities to increase the official retirement age that entitles people to a public pension. In some countries where retirees also receive relatively high private pensions in addition to their public pension, the discussion focuses on the desirability to levy higher taxes on well-to-do senior citizens to pay for part of the consequences of the ageing of the population.

These discussions make it very difficult to come up with more detailed predictions on the consequences of population ageing for public sector economics, especially in an era of economic crisis, where most European governments are also engaged in reducing public deficits in order to save the Euro and to promote a healthier economic climate. Moreover, we need to keep in mind the relation between population ageing and the competitiveness of the European economy beyond Europe. One might argue that the decline in young people entering the labour market after having completed education that taught them most recent theories, scientific insights and developments will be detrimental to the adoption of new technology. Then again, what employers say about older workers loyalty, their ability to take into consideration (older) customers' needs and desires and their dedication may help to create tailor-made products and find tailor-made solutions for customers' problems. Consequently, the ageing of the labour force might help Europe to move away from bulk production to specialized tailor-made products despite the economic crisis.

\section{Check Your Progress: A Quiz on Economic Gerontology}

Question 6.1: Why do older people sometimes have problems to find a job? (multiple answers apply)

(a) Older people might have health problems, which can make it hard to carry out physically demanding jobs

(b) Older people might not be interested in working anymore

(c) Employers might be prejudiced against older workers

(d) Older people might not be informed about the latest technological developments

(e) All of the above. 
Question 6.2: What does the social exchange theory imply about older people?

(a) Older people do not want to have social contact with younger people, because younger people do not have many resources

(b) Older people want to have social contact with younger people, because younger people have many resources

(c) Younger people do not want to have social contact with older people, because older people do not have many resources

(d) Younger people want to have social contact with older people, because older people have many resources

(e) Older people want to have contact with younger people, because everybody lost resources due to the economic crisis.

Question 6.3: How does consumption behaviour change with age?

(a) Young people consume particularly much

(b) Old people consume particularly much

(c) Middle-aged people consume particularly much

(d) Young and old people consume particularly much

(e) Middle-aged and old people consume particularly much.

Question 6.4: In which areas does consumption increase in old age? (Multiple answers possible)

(a) Food

(b) Transportation

(c) Heating

(d) Health

(e) Leisure

Question 6.5: Which older Europeans are particularly likely to work? (Multiple answers apply)

(a) Those with a low educational level

(b) Those with an intermediate educational level.

(c) Those with a high educational level.

(d) Those in Northern and Continental Europe.

(e) Those in Southern and Eastern Europe.

\section{References}

Aleksandrowicz, P. (2011). Age and stereotypes. European Policy Brief, April 2011. Vechta: 'Activating Senior Potential in Ageing Europe' Project.

Atkinson, B., \& Marlier, E. (2010). Income and living conditions in Europe. Luxembourg: Publication Office of the European Union.

Becker, G. S. (1962). Investment in human capital: A theoretical analysis. Journal of Political Economy, LXX, 9-49.

Birren, J. E. (Ed.). (2007). Encyclopedia of gerontology (2nd ed.) (pp. 330-336). San Diego: Academic Press. 
Boxall, P., \& Purcell, J. (2003). Strategy and human resource management. New York: Palgrave Macmillan.

Cowgill, D. (1974). The aging of populations and societies. Annals of the American Academy of Political and Social Science., 415(29), 1-18.

Dannefer, D., \& Phillipson, C. (Eds.). (2010). The SAGE handbook of social gerontology. London: Sage.

De Grip, A., \& Van Loo, J. (2002). The economics of skills obsolescence: a review. Research in Labor Economics, 21, 1-26.

Dorn, D., \& Sousa-Poza, A. (2010). 'Voluntary' and 'involuntary' early retirement: An international analysis. Applied Economics, 42(4), 427-438.

Estes, C. L., \& Phillipson, C. (2007). Critical gerontology. In J. E. Birren (Ed.), Encyclopedia of gerontology (2nd ed., pp. 330-336). San Diego: Academic Press.

Estes, C.L. (Ed.) (2001/2009) Social policy \& ageing. A critical perspective. Thousand Oaks: Sage.

Eurostat (2009) Mean consumption expenditure by age of the reference person (in PPS). Excel file. http://appsso.eurostat.ec.europa.eu/nui/show.do?dataset=hbs_exp_t135\&lang=en. Accessed 19 June 2012.

Eurostat (2012a). Employment rate, by highest level of education attained. Excel file. http://epp. eurostat.ec.europa.eu/tgm/table.do?tab $=$ table \&init $=1 \&$ language $=$ en $\&$ pcode $=$ tsdec $430 \& \mathrm{plu}$ gin $=0$. Accessed 19 June 2012.

Eurostat (2012b). Employment rate of older workers by sex. Excel file. http://epp.eurostat.ec. europa.eu/tgm/table.do $? \mathrm{tab}=$ table $\&$ init $=1 \&$ language $=$ en $\&$ pcode $=$ tsiem020\&plugin $=0$. Accessed 19 June 2012.

Eurostat (2012c). Mean and median income by age and sex. Excel file. http://appsso.eurostat.ec. europa.eu/nui/show.do?dataset=ilc_di03\&lang=en. Accessed 19 June 2012.

Havighurst, R. J., Neugarten, B. L., \& Tobin, S. S. (1968). Disengagement and patterns of aging. In B. Neugarten (Ed.), Middle age and aging: a reader in social psychology (pp. 161-172). Chicago: University of Chicago Press.

Hershey, D. A., Henkens, K., \& Van Dalen, H. P. (2010). What drives retirement income worries in Europe? A multilevel analysis. European Journal of Ageing, 7(4), 301-311.

Jehoel-Gijsbers, G., \& Vrooman, C. (2008). Social exclusion of the elderly: a comparative study of EU member states. CEPS, ENEPRI Research Report No. 57. Brussels: The Centre for European Policy Studies.

Litwin, H., \& Attias-Donfut, C. (2009). The inter-relationship between formal and informal care: a study in France and Israel. Ageing and Society, 29(1), 71-91.

Marshall, V. (1996). Sociology, psychology, and the social sciences. In R. Binstock \& L. George (Eds.), Handbook of aging and the social sciences (pp. 12-20). San Diego: Academic Press.

Mayhew, K., \& Rijkers, B. (2004). How to improve the human capital of older workers, or the sad tale of the magic bullet. Report. http://www.oecd.org/dataoecd/3/39/34932028.pdf. Accessed 20 June 2012.

Parsons, D. O. (1972). Specific human capital: an application to quit rates and layoff rates. Journal of Political Economy, 80(6), 1120-1143.

Perek-Bialas, J., \& Turek, K. (2011). Organisation-level policy towards older workers in Poland. International Journal of Social Welfare., 21(S1), S101-S116

Polachek, S. W., \& Siebert, W. S. (1993). The economics of earnings. Cambridge: Cambridge University Press.

Polivka, L., \& Estes, C. L. (2009). The economic meltdown of old age politics. Generations, $33(3), 56-62$.

Quadagno, J. (2011). Aging and the life course. An introduction to social gerontology. Boston: McGraw-Hill.

Riley, M. W. (1971). Social gerontology and the age stratification of society. The Gerontologist, $11(1), 79-87$.

Riley, M. W., \& Riley, J. W. (2000). Age integration: Conceptual and historical background. The Gerontologist, 40(3), 266-270. 
Schulz, J. H. (2001). The economics of aging. Westport: Auburn House.

Schippers, J., Conen, W., \& Henkens, K. (2011). Extending working lives in Europe: employers' opinions and actions. In K. Busch, M. Flore, H. Kohl, \& H. Schlatermund (Eds.), Socially imbalanced Europe-socio-political proposals in times of crisis (pp. 206-216). Pontypool: Merlin Press.

Taylor, P. E., \& Walker, A. (1994). The ageing workforce—employers' attitudes towards older people. Work, Employment \& Society, 8(4), 569-591.

Taylor, P. E., \& Walker, A. (1998). Employers and older workers: Attitudes and employment practices. Ageing and Society, 18(6), 641-658.

Thijssen, J. G. L., \& Van Der Heijden, B. I. J. M. (2003). Evaporated talent? Problems with talent development during the career. International Journal of Human Resources Development and Management, 3(2), 154-170.

Thijssen, J., \& Walter, E. (2006). Identifying obsolescence and related factors among elderly employees. Conference paper. http://www.ufhrd.co.uk/wordpress/?p=1185. Accessed 7 June 2012.

Walker, A., \& Maltby, T. (2012). Active ageing: a strategic policy solution to demographic ageing in the European Union. International Journal of Social Welfare, 21(S1), S117-S130.

World Health Organization. (2012). Active ageing. A policy framework.. Madrid: World Health Organization.

Wise, D. A. (Ed.). (2009). Developments in the economics of aging. Chicago: The University of Chicago Press.

Wise, D. A. (Ed.). (2010). Research findings in the economics of aging. Chicago: The University of Chicago Press.

Van Dalen, H., Henkens, K., \& Schippers, J. (2009). Dealing with older workers in Europe: A comparative survey of employers' attitudes and actions. Journal of European Social Policy, 19(1), 47-60.

Vrooman, J. C. (Ed.). (2008). The elderly poor in the EU's new member states. CEPS-ENEPRI Research Report No. 60. Brussels: The Centre for European Policy Studies.

Zaidi, A. (2010). Poverty risks for older people in EU countries. Policy Brief No. 11. Vienna: Centre of Social Welfare Policy and Research.

\section{Recommended Readings}

Bond, J., Peace, S., Dittmann-Kohli, F., \& Westerhof, G. J. (Eds.). (2007). Ageing in society. European perspective on gerontology (3rd ed.). London: Sage.

This volume discusses different topics concerning ageing from a European perspective.

Taylor, P. (Ed.). (2008). Ageing labour forces: Promises and prospects. Cheltenham: Edward Elgar.

This book gives an overview of the discussions around ageing workers.

Van Dalen, H. P., Henkens, K., \& Schippers, J. J. (2010). How do employers cope with an ageing workforce? Views from employers and employees. Demographic Research, 22(32), $1015-1036$.

This article investigates how Dutch employers deal with the challenges of population ageing. 